DOI: http://dx.doi.org/10.21276/ap.2019.8.2.5

Original article

\title{
In vitro evaluation of selected Indian spices for $\alpha$-amylase and $\alpha$-glucosidase inhibitory activities and their spice-drug interactions
}

\author{
Nupur Mehrotra*, Kaustubh Jadhav, Swati Rawalgaonkar, Sara Anees Khan and Badal Parekh \\ Department of Biochemistry, SVKM's Mithibai College of Arts, Chauhan Institute of Science \& Amrutben Jivanlal College \\ of Commerce and Economics (Autonomous), Vile Parle (West), Mumbai 400 056, Maharashtra, India
}

Received October 12, 2019: Revised December 10, 2019: Accepted December 13, 2019: Published online December 30, 2019

\begin{abstract}
India is believed to be crowned as the diabetes capital of the world by 2030. Considering the same, the present study was undertaken to elucidate the antidiabetic potential of selected Indian spices, viz., Cinnamomum zeylanicum Blume, Cuminum cyminum L., Laurus nobilis L., Piper nigrum L. and Elettaria cardamomum (L.) Maton. Phytochemical constituents of the spices were qualitatively identified and enzyme inhibitory assays performed. The study used $50 \%$ hydroacetone extracts of the above-mentioned five spices to evaluate in vitro $\alpha$-amylase and $\alpha$-glucosidase inhibitory activities. $\mathrm{The} \mathrm{IC}_{50}$ for $\alpha$-amylase inhibitory activity were $706.04 \pm 0.07,517.51 \pm 0.09,349.41 \pm 0.12,573.21 \pm 0.08$ and $376.18 \pm 0.12 \mathrm{~g} / \mathrm{ml}$, while those for $\alpha$-glucosidase inhibitory activity were $243.92 \pm 0.13,386.73 \pm 0.11,203.01$ $\pm 0.15,269.92 \pm 0.14$ and $182.85 \pm 0.16 \mathrm{~g} / \mathrm{ml}$ for C. zeylanicum, C. cyminum, L. nobilis, P. nigrum and E. cardamomum respectively. Statistical analysis suggests that the highest $\alpha$-amylase inhibitory activity was exhibited by $L$. nobilis and $E$. cardamomum while the highest $\alpha$-glucosidase inhibitory activity was observed for $E$. cardamomum. Diabetes is a disorder associated with many complications and diabetics generally consume spices as nutraceuticals along with their drug regime. Thus, the spice-drug interaction with two commonly used drugs, viz., Acarbose-an antidiabetic and Losartanan antihypertensive were also studied. The results suggest that spice-drug interactions significantly enhanced the inhibitory activities of $\alpha$-amylase and $\alpha$-glucosidase. The maximum increase in percent $\alpha$-amylase inhibitory activity with Acarbose supplementation was observed in C. zeylanicum (74.52\%) with minimum for E. cardamomum (50.53\%) while in presence of Losartan, maximum and minimum enhancement were observed for $C$. cyminum $(48.34 \%)$ and $C$. zeylanicum $(28.19 \%)$, respectively. As for modulation of percent $\alpha$-glucosidase inhibitory activity with Acarbose, $C$. cyminum (52.42\%) showed the highest enrichment while no change was observed in the case of $P$. nigrum, while with Losartan maximal enhancement was with C. zeylanicum (19.85\%) and minimum with C. cyminum (5.4\%). Such interactions are a double-edged sword having an advantage but can also result in fatal consequences. Thus, for developing functional food having antidiabetic properties, the study of such interactions becomes significant.
\end{abstract}

Key words: Spice-drug interactions, $\alpha$-amylase inhibitory activity, $\alpha$-glucosidase inhibitory activity, Indian spices, antidiabetic

\section{Introduction}

Currently, the chronic metabolic disease, diabetes, associated with hyperglycemia, caused due to insufficient or inefficient insulin secretion, is a concern worldwide. Due to elevated blood glucose levels, the risks of micro/macro vascular damage are high and the disorder, further, is associated with reduced life expectancy and diminished quality of life (American Diabetes Association, 2010). In India, the disease is turning to be an epidemic with more than 68 million diabetic individuals, diagnosed with the disease (Wild et al.,

Author for correspondence: Dr. Nupur Mehrotra Assistant Professor, Department of Biochemistry, SVKM's Mithibai College of Arts, Chauhan Institute of Science \& Amrutben Jivanlal College of Commerce and Economics (Autonomous), Bhaktivedanta Swami Marg, Vile Parle (West), Mumbai-400056, India

E-mail: nupur.mehrotra@mithibai.ac.in

Tel.: +91-9833452122

Fax: +91-022-26130441

Copyright (c) 2019 Ukaaz Publications. All rights reserved.

Email: ukaaz@yahoo.com; Website: www.ukaazpublications.com
2004). As per a 2017 ICMR report, the prevalence of diabetes, in India, is increasing at an alarming rate, especially in people of lower economic strata from urban areas of economically developed states. This ramification of the disease in economically disadvantaged sections of Indian society is disturbing, thus requiring concern. As per published data, the number of diabetics in India is expected to increase from 31.7 million in the year 2000 to 79.4 million in 2030 (ICMR, 2017; Whiting et al., 2011). Prevention and control of diabetes can be easily achieved by incorporating more physical activity, less calorie intake and avoiding sedentary habits, but it is still a major challenge, as individuals find changing lifestyle difficult and look for a less cumbersome alternative. A simpler alternative is consumption of an antidiabetic medication, readily available, now at subsidized rates in the country. Studies in the past have shown that antidiabetic drugs as sulphonylureas, biguanides, dipeptidyl peptidase IV (DPP-IV) inhibitors, sodium-glucose co-transporter (SGLT2) inhibitors, Insulin therapy, and GLP-1 agonists, have multiple adverse reactions (Mohanty et al., 2018; Chaudhury et al., 2017). 
The regular consumption year after year along with undesirable side effects to various organs is, thus a big apprehension for use of these antidiabetics. Carbohydrate hydrolyzing enzymes, viz., $\alpha$-amylase and $\alpha$-glucosidase convert complex carbohydrates, like starch to simpler ones, facilitating the release of glucose into the blood. The inhibition of $\alpha$-amylase delays the digestion of starch while that of $\alpha$-glucosidase impairs the digestion of disaccharides (Oboh et al., 2015), thus being an effective tool for the management of diabetes by regulating and controlling the rise of postprandial glucose level. $\alpha$-glucosidase inhibitors function by being competitive inhibitors of intestinal $\alpha$-glucosidase enzyme which is present on the microvilli (Lebovitz, 1998). Natural sources of $\alpha$-amylase and $\alpha$-glucosidase inhibitors are of great importance in folk medicine for the treatment and management of diabetes (Balaji et al., 2015; Sindhu et al., 2013).

Plant-based medicinal products have been known to mankind since ancient times and traditional herbal medicines are believed to be safe and effective with little or no side effects, providing an alternative way to manage diabetes (Subbulakshmi and Naik, 2001). Cuisines across the globe are enriched with aromas and flavors contributed by various herbs and spices. Indian cooking styles make use of many spices like Cinnamon (C. verum, C. zeylanicum, C. aromaticum and $C$. burmannii), Cumin (C. cyminum), Clove ( $S$. aromaticum), Pepper (P. nigrum) and Bay leaves (L. nobilis) and ancient Indian literature supports the use of some of these, as antidiabetic (Patil et al., 2013; Upadhyay, 2016).

E. cardamomum, or green elaichi, has been used not only in cuisines but also as an integral component of betel leaves. In vivo as well as in vitro studies demonstrate the effectiveness of the spice in the treatment of diarrhea, constipation, colic distress and hypertension (Sharma et al., 2011) and as an analgesic, antispasmodic, antiinflammatory, antioxidant, antimicrobial, anticonvulsant and sedative (Suneetha and Krishnakantha, 2005). The methanolic and aqueous extracts of the spice in vitro are reported to possess $\alpha$-glucosidase and $\alpha$-amylase inhibition at $1 \mathrm{mg} / \mathrm{ml}$, thus proving to be useful as an antidiabetic (Ahmed et al., 2017). Further, a 10 -week long randomized placebo-controlled clinical trial by Aghasi et al. $(2018,2019)$ to analyze blood glucose levels in type 2 diabetic patients reported a decrease in HbAlc and insulin level in type 2 diabetes mellitus patients. An ethanolic cardamom leaves extract has been found to have the potential to be used as a functional food component for therapy in the diabetic patient (Winarsi et al., 2014).

Cinnamon has been used for its medicinal properties across the world for as long as 5000 years (Singh et al., 2018). A study by Khan et al. (2003) analyzed the effect of cinnamon on levels of glucose and lipids in type 2 diabetics and recommended the supplementation of 1-6 $\mathrm{g}$ of cinnamon to the diet, thereby facilitating a significant decrease in serum glucose levels. The hypoglycemic activity of cinnamon may be attributed to: (a) stimulation of the release of insulin as well as insulin receptor signaling, (b) inhibition of various enzymes involved in metabolism and, thus release of simple carbohydrates in blood (c) alteration of cellular glucose uptake by probably increased glucose transporter-4 receptor synthesis (Ali et al., 2018). Kamble and Rambhimaiah (2013) studied the antidiabetic effect of aqueous extract of $C$. cassia alone and in combination with glibenclamide in alloxan-induced diabetic rats. The study reported that the combination when given for 15 days caused a more significant reduction in blood glucose level than either drug is given alone.

Cumin (C. cyminum), family Apiaceae, is used regularly in every Indian household. It has been prescribed for its potential as a stomachic, diuretic, carminative, emmenagogic, antispasmodic, antimicrobial as well as a fungicide (Joshi, 2000). Srivastava et al. (2013), studied the in vivo effects of the ethanolic extract of cumin seeds and found it to possess $\alpha$-glucosidase inhibitory activity with $\mathrm{IC}_{50}$ of $100 \mu \mathrm{g} / \mathrm{ml}$ as compared to a known $\alpha$-glucosidase inhibitor drug Acarbose that has an $\mathrm{IC}_{50}$ close to $25 \mu \mathrm{g} / \mathrm{ml}$. Administration of $C$. cyminum supplement to type 2 diabetics leads to a fall in the serum levels of insulin, FBS and glycosylated hemoglobin along with a decrease in the inflammatory indices of TNF- $\alpha$ and hsCRP accompanied by an increase in the adiponectin serum levels, thus also facilitating better control of the complications that arise due to the same (Jafari et al., 2017). The antidiabetic effect of cumin seeds can be attributed to the enhancement of insulin secretion and the amelioration of diabetes-induced oxidative stress by exhibiting free radical scavenging activity in streptozocin induced diabetic rats (Joshi, 2000).

Traditionally, black pepper is widely used for treating diarrhea, dyspepsia, cholera, and gastric ailments. The spice is rich in various active phytochemicals such as flavones, steroids, terpenes, and alkaloids of which, piperine is the major alkaloid (Khaliq et al., 2015). According to the study of Kavitha et al. (2018), a 30\% ethanolic extract exhibited $67.93 \% \alpha$-amylase inhibitory activity at $1000 \mu \mathrm{g} / \mathrm{ml}$. In vivo studies have suggested that the antidiabetic effect of black pepper is attributed to either inhibition of the increase in insulin output or that of glucose intestinal absorption or by enhancing glucose metabolism or combination of all (Bandigari, 2018).

Bay leaf, L. nobilis, member of Lauraceae family, is a very popular culinary spice. The use of this spice as a herbal medicine with pharmacological activities as antibacterial, antifungal, antidiabetic and anti-inflammatory (Fang et al., 2005). Khan et al. (2009) demonstrated that daily consumption for 30 days (1-3 g/day), decreases the risk for diabetes and is beneficial for type 2 diabetes. Abdulrahim Aljamal (2011) showed that 4 weeks of bay leaves supplementation improves plasma glucose levels in type 2 diabetics. The extract also exhibits potential anti- $\alpha$-amylase activity in combination with soursop leaves (Berawi et al., 2017).

The present study uses hydroacetone extracts of the abovementioned five spices to evaluate in vitro $\alpha$-amylase and $\alpha$-glucosidase inhibitory activities. The consumption of these nutraceuticals for their antidiabetic potential is generally not monitored by physicians and further, the regular drug regime of the individual is not compromised. The complexity of the human organization could lead to interactions between the spice and the drug, being hazardous via adverse drug events, or, advantageous through enhancement of drug pharmacodynamics (Gupta et al., 2017a; Kamath and Adiga, 2014). This field has not been largely explored, especially with spices consumed in our country.

The patients under medication prescribed by physicians, along with the use of herbal remedies may enhance the possibility of the occurrence of polypharmacosis. The interactions could be spicedrug or food-drug in nature. The food-drug interactions can affect 
the bioavailability of a drug, while the mechanism of spice-drug interaction remains to be elucidated.

In the current study, Acarbose, an antidiabetic drug that functions as an $\alpha$-glucosidase inhibitor, is used for studying spice-drug interactions. Furthermore, diabetes and hypertension frequently co-exist and so interaction with an antihypertensive drug as Losartan, an ACE inhibitor, is evaluated as well. To maximize the efficacy of herbal remedies, prior knowledge about additive, synergistic, antagonist, or unidentified effect is desirable. This information can be of great significance to develop functional food having antidiabetic properties.

\section{Materials and Methods}

\subsection{Preparation of spice extract}

The spices were procured locally and authenticated by Dr. Bindu Gopalakrishnan, Department of Botany, Mithibai College (Autonomous), Mumbai. The spices selected were Cinnamomum zeylanicum Blume (stem bark), Cuminum cyminum L. (seeds), Laurus nobilis L. (leaves), Piper nigrum L. (seeds) and Elettaria cardamomum (L.) Maton (seeds inside the pods) with Herbarium numbers: MIT0130, MIT0113, MIT0135, MIT0109, MIT0076, respectively. The spices were oven-dried to remove any moisture at $45^{\circ} \mathrm{C}$ and thereafter, finely powdered and sieved (sieve pore size $=0.3 \mathrm{~mm} \times 0.5 \mathrm{~mm}$ ). $0.2 \mathrm{gm}$ of this powder was extracted in 5 $\mathrm{ml} 50 \%$ hydroacetone on a rotary shaker for $24 \mathrm{~h}$. The extract was filtered and the filtrate dried over water bath at $45^{\circ} \mathrm{C}$. The dried extract was weighed and the percent yield was calculated using the formula:

Weight of dried spice extract/weight of spice powder $* 100$

Lastly, the extract was reconstituted in a minimum amount of dimethylsulphoxide (DMSO) and dilutions of $10 \mu \mathrm{g} / \mathrm{ml}, 20 \mu \mathrm{g} / \mathrm{ml}$, $40 \mu \mathrm{g} / \mathrm{ml}, 80 \mu \mathrm{g} / \mathrm{ml}$ and $160 \mu \mathrm{g} / \mathrm{ml}$ were prepared for the study.

\subsection{Phytochemical and biomolecule analysis}

The hydroacetone extracts of the spices were tested for their phytochemical and biomolecule constituents qualitatively using modification of the methods by Soni and Sosa (2013), Modi et al. (2018) and Dahanayake et al. (2019).

\begin{tabular}{|c|c|}
\hline $\begin{array}{l}\text { Phytochemical / } \\
\text { biomolecule test }\end{array}$ & Procedure \\
\hline Molisch test & $\begin{array}{l}\text { Spice solution was mixed with } 10 \% \text { methanolic } \alpha \text {-naphthol solution and then } 4 \text { to } 5 \text { drops of concentrated } \\
\mathrm{H}_{2} \mathrm{SO}_{4} \text { was added along the side of the test tube. A violet ring indicates the presence of glycoside or sugar. }\end{array}$ \\
\hline Barfoed's test & $\begin{array}{l}\text { To spice extract was added Barfoed's reagent and it was heated in a boiling water bath for } 2 \text { minutes. The } \\
\text { formation of a red precipitate indicates the presence of monosaccharides. }\end{array}$ \\
\hline Fehling's test & $\begin{array}{l}\text { Free sugars: To spice extract was added Fehling's reagent, boiled in the water bath for } 5 \text { minutes. The } \\
\text { formation of red-colored precipitate indicates a positive test. For Combined sugars: } 5 \mathrm{ml} \text { of dilute } \mathrm{HCl} \text { was } \\
\text { added to the spice extract and heated in a boiling water bath for } 5 \text { minutes. Then it was neutralized using } \\
\mathrm{NaOH} \text {. Fehling's reagent was added to this test tube. Reddish colored precipitate indicates the test is positive. }\end{array}$ \\
\hline Soluble starch & $\begin{array}{l}\text { The spice extract was boiled with } 1 \mathrm{ml} 5 \% \mathrm{KOH} \text {. After cooling, sulphuric acid is added to it. A yellow } \\
\text { coloration indicates the presence of starch. }\end{array}$ \\
\hline Proteins & The spice extract was mixed with biuret reagent, and purple coloration indicates a positive test. \\
\hline Alkaloids & $\begin{array}{l}\text { Spice extract was diluted in acidic solution like } 1-5 \% \mathrm{HCl} \text { and the solution thus obtained used for the } \\
\text { detection of alkaloids using various reagents. }\end{array}$ \\
\hline Mayer's test & $\begin{array}{l}\text { Spice extract was mixed with Mayer's reagent. The formation of white or buff precipitates confirms the } \\
\text { presence of alkaloids in the sample. }\end{array}$ \\
\hline Hager's test & Spice extract was mixed with Hager's reagent. A yellow precipitate confirms the presence of alkaloids in the sample. \\
\hline Flavonoids & $\begin{array}{l}\text { Spice extract was heated on a water bath and the filtrate was treated with } 10 \% \text { ferric chloride }\left(\mathrm{FeCl}_{3}\right) \text { and the presence } \\
\text { of bluish-green color indicates flavonoids. }\end{array}$ \\
\hline Steroid and sterol & $\begin{array}{l}\text { Conc. } \mathrm{H}_{2} \mathrm{SO}_{4} \text { was added into spice solution along the side of the test tube, wherein formation of two phases and } \\
\text { development of red color indicates the presence of sterol. }\end{array}$ \\
\hline Phenols & $\begin{array}{l}\text { Spice extract was mixed with } 1 \mathrm{ml} \text { of } 5 \% \mathrm{FeCl}_{3} \text { in } 90 \% \text { methanol. It was observed for blue, blue-black, or blue-green } \\
\text { color which indicates the presence of polyphenols. }\end{array}$ \\
\hline Saponin & $\begin{array}{l}\text { Powdered spice was dissolved in water and shaken well. The formation of foam, stable for } 15 \mathrm{~min} \text { or more } \\
\text { indicates the presence of saponin. }\end{array}$ \\
\hline Tannins & $\begin{array}{l}\text { Spice extract was dissolved in water and heated on a boiling water bath for } 1 \mathrm{~h} \text {. The filtrate was treated with } \\
\mathrm{FeCl}_{3} \text { and observed for the formation of a dark green color. }\end{array}$ \\
\hline Terpenoids & $\begin{array}{l}\text { To spice extract was added a few } \mathrm{ml} \text { of chloroform and concentrated sulphuric acid from the sides of the test tube. } \\
\text { The formation of a reddish-brown colored layer indicates the test is positive. }\end{array}$ \\
\hline
\end{tabular}




\subsection{Enzyme inhibitory assays}

\subsection{1 $\alpha$-amylase inhibitory assay}

The assay was conducted as per the modification of Narkhede et al. (2011) method. $0.5 \mathrm{ml}$ of spice extract (various dilutions) and $0.5 \mathrm{ml}$ of fungal $\alpha$-amylase enzyme were mixed in test tubes and incubated at $25^{\circ} \mathrm{C}$ for 30 minutes. One $\mathrm{ml}$ of $0.5 \%$ starch solution was added and further incubated at $25^{\circ} \mathrm{C}$ for $30 \mathrm{~min}$. The reaction was terminated by the addition of $0.5 \mathrm{ml}$ of $2 \mathrm{~N} \mathrm{NaOH}$ and finally $0.5 \mathrm{ml} \mathrm{3,5}$ dinitrosalicylic acid (DNSA) was added and the tubes were placed in a boiling water bath for $5 \mathrm{~min}$. On cooling, the contents were diluted with $6 \mathrm{ml}$ distilled water and extinction measured at $540 \mathrm{~nm}$. To the control and blank tubes of each concentration, plant extract and enzyme were omitted, respectively.

\subsubsection{Calculations for $\alpha$-amylase inhibitory activity}

$100 \mathrm{x}\left(\mathrm{Ext}_{540}{ }^{\prime}\right.$ Control - Ext ${ }_{540}$ ' Test $) / \mathrm{Ext}_{540}{ }^{\text {'Control. }}$

The extinction of blank was subtracted from that of the test to nullify the effect of naturally occurring reducing sugars in the spice extract.

\subsection{3 $\alpha$-glucosidase inhibitory assay}

The assay was performed by modification of the method of Geng et al. (2007). For the same, 3 test tubes, viz., blank, control and test were prepared. To the tubes were added $2 \%$ yeast $(200 \mu \mathrm{l}), 0.02 \mathrm{M}$ phosphate buffer (pH-6.8) $(100 \mu \mathrm{l})$, spice extract $(50 \mu \mathrm{l}$ of different concentrations) and distilled water $(50 \mu 1$ in control and $100 \mu \mathrm{l}$ in blank). The tubes were incubated for $10 \mathrm{~min}$. After incubation, 200 $\mu 1$ of maltose was added, and the tubes were again incubated at $37^{\circ} \mathrm{C}$ for $30 \mathrm{~min}$. The tubes were kept in a boiling water bath for $5 \mathrm{~min}$ and then cooled in an ice bath. To the individual concentration, contro and blank tubes, plant extract and enzyme, respectively were omitted. For glucose estimation, GOD/POD method was used and the extinction read at $540 \mathrm{~nm}$.

\subsubsection{Calculations for $\alpha$-glucosidase inhibitory activity}

Amount of glucose in control: Ext $_{540}{ }^{\text {'Control / Ext }}{ }_{540}$ 'Standard x 100 $=\mathrm{A} \mathrm{g} / \mathrm{ml}$.

Amount of glucose present in the test: Ext $_{540}$ 'Test/ Ext ${ }_{540}$ 'Standard $\mathrm{x} 100=\mathrm{B} \mathrm{g} / \mathrm{ml}$.

$\left(\right.$ Ext $_{540}{ }^{\prime}$ Test $=$ Ext $_{540}$ 'Test - Ext $_{540}$ 'Blank $)$

The extinction of blank was subtracted from that of the test to nullify the effect of naturally occurring reducing sugars in the spice extract.

$\alpha$-glucosidase inhibitory activity was calculated as: A-B/A x 100

where $\mathrm{A}=$ Amount of glucose in control and $\mathrm{B}=$ Amount of glucose in the test

For estimating the $\alpha$-amylase and $\alpha$-glucosidase inhibitory activities of drugs, the same procedure was used, with the spice extract being replaced by the drug, while to study the spice-drug interaction, both spice and drug were simultaneously used.

\subsection{Statistical analysis}

The $\mathrm{IC}_{50}$ were calculated using the $\mathrm{IC}_{50}$ software. The data were expressed as mean \pm standard error (SE) for $n=5$. Statistical analysis of the results was performed using the Student's t-test. $p<0.05$ was considered to be statistically significant. Computation of two way ANOVA was performed to determine the spice amongst the ones studied, possessing a better enzyme inhibitory activity.

\section{Results}

\subsection{Percent yield}

The percent yield was calculated by considering the weight of dried extract obtained post $24 \mathrm{~h}$ extraction, filtration and drying with respect to the spice powder. The yields of extracts obtained are depicted in Table 1.

\subsection{Phytochemical and biomolecule analysis}

The current study was conducted with a $50 \%$ hydroacetone extract of the spices. The results of the phytochemical and biomolecule analysis are depicted in Table 2 .

Table 1: Yield of plant extracts post $24 \mathrm{~h}$ extraction process

\begin{tabular}{|l|l|}
\hline Spice & $\%$ Yield \\
\hline C. zeylanicum & $4.89 \pm 0.05$ \\
C. cyminum & $5.21 \pm 0.10$ \\
L. nobilis & $4.93 \pm 0.02$ \\
P. nigrum & $5.10 \pm 0.02$ \\
E. cardamomum & $4.51 \pm 0.06$ \\
\hline
\end{tabular}

The values represented are mean $\pm S E$, where $n=5$.

\subsection{Enzyme inhibitory activities}

Ancient Indians, since time immemorial, have been using spices and other herbs and plants for therapy of various disorders and dysfunction of the human physiology. Various herbal extracts have been cited as potent antidiabetic. The current study evaluated five common Indian spices for their disruption of carbohydrate metabolism via $\alpha$-amylase and $\alpha$-glucosidase inhibitory activity.

$\alpha$-amylase inhibitory activity

A dose-dependent increase in the inhibitory activity of hydroacetone extracts towards the carbohydrate metabolizing enzyme, $\alpha$-amylase, was observed, between the concentration range 10-160 $\mathrm{g} / \mathrm{ml}$ for spices (Table 3, Figure 1). Between the lowest and the highest concentrations of spice studied $(10 \mathrm{~g} / \mathrm{ml}$ and $160 \mathrm{~g} / \mathrm{ml})$, the percent increase was $54.98 \%, 80.71 \%, 82.94 \%, 89.72 \%$ and $78.47 \%$ for $C$. zeylanicum, C. cyminum, L. nobilis, P. nigrum, and E. cardamomum, respectively. The $\mathrm{IC}_{50}$ for the spices were 706.04, 517.51, 349.41, 573.21 and $376.18 \mu \mathrm{g} / \mathrm{ml}$, respectively and are presented in Table 5. Statistical analysis suggests that amongst the spices studied, better inhibitory activities were observed for L. nobilis and E. cardamomum.

\section{$\alpha$-glucosidase inhibitory activity}

For hyrdroacetone extract, C. zeylanicum, C. cyminum, L. nobilis, $P$. nigrum, and $E$. cardamomum, yeast $\alpha$-glucosidase inhibitory activity, was investigated and the results are shown in Table 4, Figure 2. The characteristic increase in blood glucose levels in diabetes can be regulated by the inhibition of the above-mentioned enzyme, thus facilitating sudden fluctuations in plasma glucose levels. A dosedependent increase was observed and the percent increase between the extreme concentrations studied was $56.15 \%, 74.63 \%, 58.09 \%$, $62.14 \%$ and $59.39 \%$ for C. zeylanicum, C. cyminum, L. nobilis, P. nigrum, and E. cardamomum, respectively. $\mathrm{The}_{\mathrm{IC}} \mathrm{C}_{50}$ for the spices were $243.92,386.73,203.01,269.92$ and $182.85 \mu \mathrm{g} / \mathrm{ml}$, respectively and are presented in Table 5. Statistical analysis suggests that amongst the spices studied, better inhibitory activity was observed for E. cardamomum. 
Table 2: Phytochemical and biomolecule analysis of $50 \%$ hydroacetone extract of spices

\begin{tabular}{|l|c|c|c|c|c|}
\hline $\begin{array}{l}\text { Phytochemicals and } \\
\text { biomolecules }\end{array}$ & C. zeylanicum & C. cyminum & L. nobilis & P. nigrum & E. cardamomum \\
\hline A) Carbohydrates & + & + & + & + & + \\
i) Reducing sugars & + & - & - & - & - \\
ii) Combined sugars & - & + & - & - & - \\
iii) Soluble starch & - & + & + & - & - \\
B) Protein & - & - & - & - & + \\
C) Alkaloids & - & + & - & + & + \\
i) Mayer's test & - & + & - & + \\
ii) Hager's test & + & + & + & + & + \\
D) Flavonoids & + & - & + & - \\
E) Steroid \& Sterols & + & + & - & - & + \\
F) Phenols & - & - & - & - \\
G) Saponins & + & + & + & + \\
H) Tanins & + & + & + & + \\
I) Terpenoids & + & & + \\
\hline
\end{tabular}

Legend: + represents presence of the phytochemical - represents absence of the phytochemical.

Table 3: Percent $\alpha$-amylase inhibitory activity of spices

\begin{tabular}{|c|c|c|c|c|c|}
\hline \multicolumn{5}{|c|}{ Percent $\boldsymbol{\alpha}$-amylase inhibitory activity } \\
\hline Concentration ( g/ml) & C. zeylanicum & C. cyminum & L. nobilis & \multicolumn{1}{c|}{$\boldsymbol{P}$ nigrum } & E. cardamomum \\
\hline $\mathbf{1 0}$ & $1.63 \pm 0.01 \%$ & $3.27 \pm 0.04 \%$ & $4.19 \pm 0.35 \%$ & $1.58 \pm 0.13 \%$ & $5.26 \pm 0.34 \%$ \\
$\mathbf{2 0}$ & $2.32 \pm 0.04 \%$ & $4.83 \pm 0.13 \%$ & $11.72 \pm 0.69 \%$ & $4.01 \pm 0.30 \%$ & $9.68 \pm 0.28 \%$ \\
$\mathbf{4 0}$ & $3.89 \pm 0.25 \%$ & $8.08 \pm 0.06 \%$ & $15.59 \pm 0.58 \%$ & $8.05 \pm 0.11 \%$ & $12.14 \pm 0.36 \%$ \\
$\mathbf{8 0}$ & $6.73 \pm 0.16 \%$ & $12.49 \pm 0.13 \%$ & $23.04 \pm 0.11 \%$ & $11.56 \pm 0.58 \%$ & $16.55 \pm 0.35 \%$ \\
$\mathbf{1 6 0}$ & $12.03 \pm 0.09 \%$ & $16.95 \pm 0.12 \%$ & $24.57 \pm 0.19 \%$ & $14.72 \pm 0.72 \%$ & $24.43 \pm 0.08 \%$ \\
\hline
\end{tabular}

The values represented are mean \pm SE, where $n=5$.

Table 4: Percent $\alpha$-glucosidase inhibitory activity of spices

\begin{tabular}{|c|c|c|c|c|c|}
\hline \multicolumn{6}{|c|}{ Percent $\alpha$-glucosidase inhibitory activity } \\
\hline Concentration ( $\mathrm{g} / \mathrm{ml})$ & C. zeylanicum & C. cyminum & L. nobilis & P. nigrum & E. cardamomum \\
\hline 10 & $16.05 \pm 0.33 \%$ & $6.27 \pm 0.53 \%$ & $17.52 \pm 1.33 \%$ & $13.26 \pm 0.48 \%$ & $17.83 \pm 0.50 \%$ \\
\hline 20 & $20.09 \pm 0.50 \%$ & $12.29 \pm 0.62 \%$ & $21.48 \pm 1.50 \%$ & $16.80 \pm 0.25 \%$ & $25.10 \pm 0.80 \%$ \\
\hline 40 & $27.20 \pm 1.13 \%$ & $16.88 \pm 0.29 \%$ & $29.30 \pm 1.10 \%$ & $20.40 \pm 0.34 \%$ & $31.49 \pm 0.78 \%$ \\
\hline 80 & $33.32 \pm 0.42 \%$ & $19.58 \pm 0.41 \%$ & $33.60 \pm 1.07 \%$ & $23.73 \pm 0.51 \%$ & $37.85 \pm 0.42 \%$ \\
\hline 160 & $36.60 \pm 0.50 \%$ & $24.71 \pm 0.26 \%$ & $41.80 \pm 0.32$ & $35.02 \pm 0.10 \%$ & $43.91 \pm 0.42 \%$ \\
\hline
\end{tabular}

The values represented are mean \pm SE, where $\mathrm{n}=5$

Table 5: $\mathrm{IC}_{50}$ for $\alpha$-amylase and $\alpha$-glucosidase inhibitory activity $(\mu \mathrm{g} / \mathrm{ml})$ on Acarbose and Losartan supplementation

\begin{tabular}{|c|c|c|c|c|c|c|}
\hline \multirow[t]{3}{*}{ Spice } & \multicolumn{3}{|c|}{ IC $_{50}$ of $\alpha$-amylase inhibitory activity in $\mu \mathrm{g} / \mathrm{ml}$} & \multicolumn{3}{|c|}{ IC $_{50}$ of $\alpha$-glucosidase inhibitory activity in $\mu \mathrm{g} / \mathrm{mI}$} \\
\hline & \multirow[b]{2}{*}{ Spice } & \multicolumn{2}{|c|}{ Supplementation } & \multirow[b]{2}{*}{ Spice } & \multicolumn{2}{|c|}{ Supplementation } \\
\hline & & Acarbose & Losartan & & Acarbose & Losartan \\
\hline $\begin{array}{l}\text { C. zeylanicum } \\
\text { C. cyminum } \\
\text { L. nobilis } \\
P . \text { nigrum } \\
\text { E. cardamomum }\end{array}$ & $\begin{array}{l}706.04 \pm 0.07 \\
517.52 \pm 0.09 \\
349.41 \pm 0.12 \\
573.22 \pm 0.08 \\
376.18 \pm 0.12\end{array}$ & $\begin{array}{l}179.91 \pm 0.13^{*} \\
193.33 \pm 0.12^{*} \\
162.20 \pm 0.19^{*} \\
247.82 \pm 0.08^{*} \\
186.74 \pm 0.16^{*}\end{array}$ & $\begin{array}{l}507.01 \pm 0.08^{*} \\
267.33 \pm 0.12^{*} \\
230.26 \pm 0.14^{*} \\
334.02 \pm 0.12^{*} \\
235.25 \pm 0.15^{*}\end{array}$ & $\begin{array}{l}243.92 \pm 0.13 \\
386.73 \pm 0.11 \\
203.01 \pm 0.15 \\
269.92 \pm 0.14 \\
182.85 \pm 0.16\end{array}$ & $\begin{array}{l}150.04 \pm 0.10^{*} \\
184.00 \pm 0.11^{*} \\
151.98 \pm 0.10^{*} \\
270.23 \pm 0.11 \\
163.72 \pm 0.13\end{array}$ & $\begin{array}{l}195.50 \pm 0.15^{*} \\
365.85 \pm 0.12 \\
162.30 \pm 0.15^{*} \\
248.57 \pm 0.14 \\
153.49 \pm 0.14\end{array}$ \\
\hline
\end{tabular}

The values represented are mean \pm SE, where $n=5$.

Mean values superscripted by $*$ are statistically significant at $p<0.05$. 


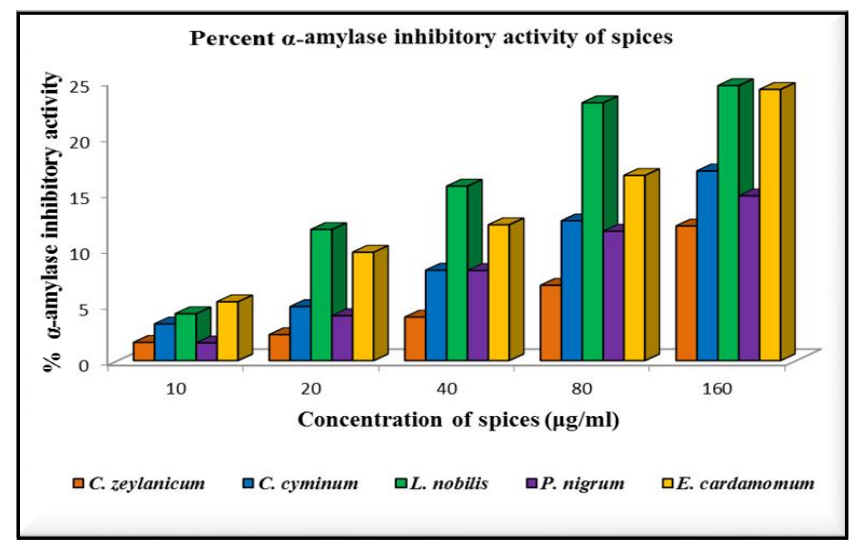

Figure 1: Percent $\alpha$-amylase inhibitory activity of spices.

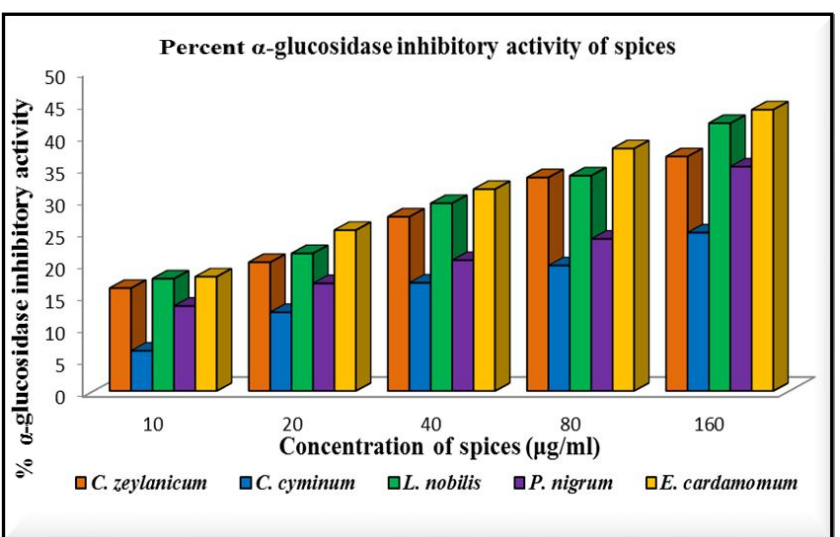

Figure 2: Percent $\alpha$-glucosidase inhibitory activity of spices.

\subsection{Spice-drug interactions}

The spices within the preview of the current study possess antidiabetic activity as indicated by their potential to mediate carbohydrate metabolism by inhibiting the two major enzymes in carbohydrate metabolism, viz., $\alpha$-amylase and $\alpha$-glucosidase. Since herbal remedies are believed to be 'safe' with 'no adverse reactions', they are consumed without any medical advice.

In our study, we investigated the effect on the inhibitory activities of the two enzymes on supplementation with drugs. The drugs under study are Acarbose, an antidiabetic and Losartan, an antihypertensive. The results suggest a significant increase in the inhibitory activities of the enzymes on drug supplementation. The results are indicated in Table 6-10a and $\mathrm{b}$ and Figure 3-7a and $\mathrm{b}$.

Table 6a: Percent $\alpha$-amylase inhibitory activity of C. zeylanicum and its interaction with Acarbose and Losartan

\begin{tabular}{|c|c|c|c|}
\hline $\begin{array}{c}\text { Concentration } \\
(\mathbf{~ g / m l )}\end{array}$ & C. zeylanicum & $\begin{array}{c}\text { C. zeylanicum }+ \\
\text { Acarbose } \\
\text { supplementation }\end{array}$ & $\begin{array}{c}\text { C. zeylanicum }+ \\
\text { Losartan } \\
\text { supplementation }\end{array}$ \\
\hline $\mathbf{1 0}$ & $1.63 \pm 0.01 \%^{*}$ & $20.31 \pm 0.73 \%^{*}$ & $8.05 \pm 0.31 \%^{*}$ \\
$\mathbf{2 0}$ & $2.32 \pm 0.04 \%^{*}$ & $31.29 \pm 0.18 \%^{*}$ & $12.24 \pm 0.28 \%^{*}$ \\
$\mathbf{4 0}$ & $3.89 \pm 0.25 \%^{*}$ & $35.33 \pm 0.31 \%^{*}$ & $16.94 \pm 0.26 \%^{*}$ \\
$\mathbf{8 0}$ & $6.73 \pm 0.16 \%^{*}$ & $39.41 \pm 0.18 \% \%^{*}$ & $20.74 \pm 0.26 \%^{*}$ \\
$\mathbf{1 6 0}$ & $12.03 \pm 0.09 \%^{*}$ & $45.11 \pm 0.20 \% \%^{*}$ & $21.17 \pm 0.88 \%{ }^{*}$ \\
\hline
\end{tabular}

The values represented are mean $\pm S E$, where $n=5$.

Mean values superscripted by $*$ are statistically significant at $p<0.05$.

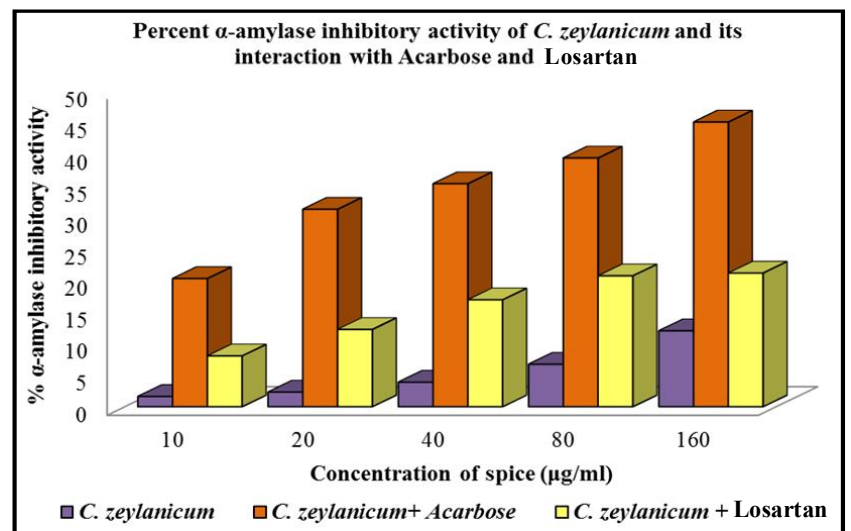

Figure 3a: Percent $\alpha$-amylase inhibitory activity of $C$. zeylanicum and its interaction with Acarbose and Losartan.

Table 6b: Percent $\alpha$-glucosidase inhibitory activity of $C$. zeylanicum and its interaction with Acarbose and Losartan

\begin{tabular}{|c|c|c|c|}
\hline $\begin{array}{c}\text { Concentration } \\
(\mathbf{g} / \mathbf{m l})\end{array}$ & C. zeylanicum & $\begin{array}{c}\text { C. zeylanicum }+ \\
\text { Acarbose } \\
\text { supplementation }\end{array}$ & $\begin{array}{c}\text { C. zeylanicum }+ \\
\text { Losartan } \\
\text { supplementation }\end{array}$ \\
\hline $\mathbf{1 0}$ & $16.05 \pm 0.33 \% *$ & $32.09 \pm 0.23 \% *$ & $18.73 \pm 0.28 \% *$ \\
$\mathbf{2 0}$ & $20.09 \pm 0.50 \% *$ & $37.94 \pm 0.17 \% *$ & $22.90 \pm 0.22 \% *$ \\
$\mathbf{4 0}$ & $27.20 \pm 1.13 \% *$ & $41.01 \pm 0.18 \% *$ & $31.83 \pm 0.17 \% *$ \\
$\mathbf{8 0}$ & $33.32 \pm 0.42 \% *$ & $46.19 \pm 0.35 \% *$ & $37.24 \pm 0.18 \% *$ \\
$\mathbf{1 6 0}$ & $36.60 \pm 0.50 \% *$ & $49.08 \pm 0.27 \% *$ & $42.18 \pm 0.18 \% *$ \\
\hline
\end{tabular}

The values represented are mean \pm SE, where $\mathrm{n}=5$.

Mean values superscripted by $*$ are statistically significant at $p<0.05$.

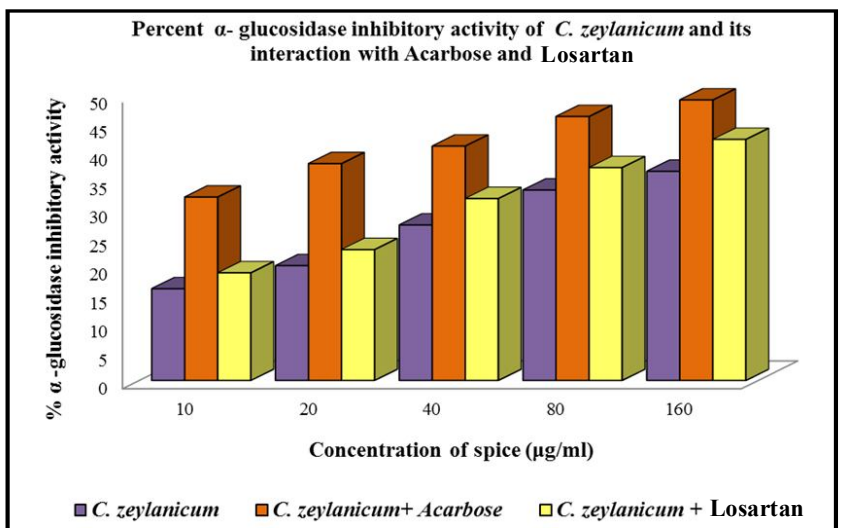

Figure 3b: Percent $\alpha$-glucosidase inhibitory activity of $C$. zeylanicum and its interaction with Acarbose and Losartan.

Table 7a: Percent $\alpha$-amylase inhibitory activity of C. cyminum and its interaction with Acarbose and Losartan

\begin{tabular}{|c|c|c|c|}
\hline $\begin{array}{c}\text { Concentration } \\
(\mathbf{g} / \mathbf{m l})\end{array}$ & C. cyminum & $\begin{array}{c}\text { C. cyminum }+ \\
\text { Acarbose } \\
\text { supplementation }\end{array}$ & $\begin{array}{c}\text { C. cyminum }+ \\
\text { Losartan } \\
\text { supplementation }\end{array}$ \\
\hline $\mathbf{1 0}$ & $3.27 \pm 0.04 \%^{*}$ & $23.56 \pm 0.32 \%^{*}$ & $15.69 \pm 0.41 \%^{*}$ \\
$\mathbf{2 0}$ & $4.83 \pm 0.13 \%^{*}$ & $31.16 \pm 0.35 \%^{*}$ & $20.89 \pm 0.19 \%^{*}$ \\
$\mathbf{4 0}$ & $8.08 \pm 0.06 \%^{*}$ & $35.14 \pm 0.33 \%^{*}$ & $24.58 \pm 0.43 \%^{*}$ \\
$\mathbf{8 0}$ & $12.49 \pm 0.13 \%^{*}$ & $39.89 \pm 0.30 \%^{*}$ & $31.26 \pm 0.23 \%^{*}$ \\
$\mathbf{1 6 0}$ & $16.95 \pm 0.12 \%^{*}$ & $44.04 \pm 0.18 \% *$ & $35.16 \pm 0.25 \%^{*}$ \\
\hline
\end{tabular}

The values represented are mean \pm SE, where $n=5$.

Mean values superscripted by $*$ are statistically significant at $p<0.05$. 


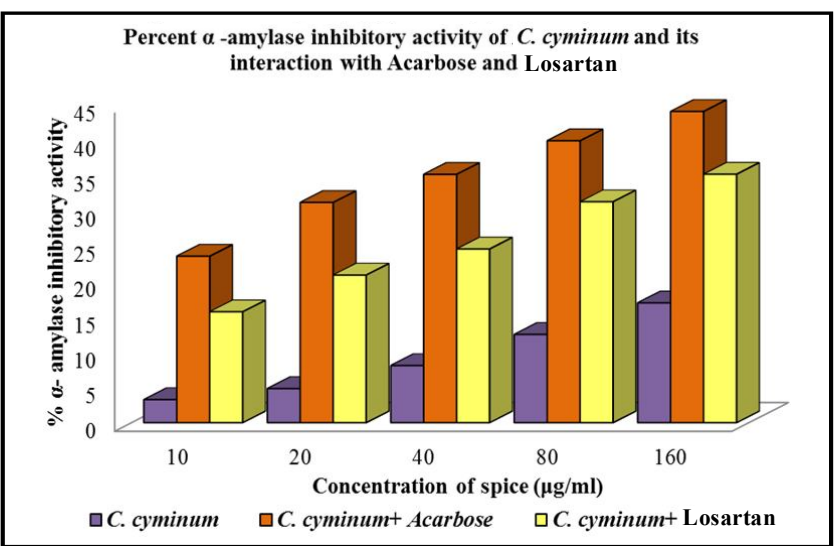

Figure 4a: Percent $\alpha$-amylase inhibitory activity of $C$. cyminum and its interaction with Acarbose and Losartan.

Table 7b: Percent $\alpha$-glucosidase inhibitory activity of $C$. cyminum and its interaction with Acarbose and Losartan

\begin{tabular}{|c|r|c|c|}
\hline $\begin{array}{c}\text { Concentration } \\
(\mathbf{g} / \mathbf{m l})\end{array}$ & $\boldsymbol{C}$. cyminum & $\begin{array}{c}\text { C. cyminum }+ \\
\text { Acarbose } \\
\text { supplementation }\end{array}$ & $\begin{array}{c}\text { C. cyminum }+ \\
\text { Losartan } \\
\text { supplementation }\end{array}$ \\
\hline $\mathbf{1 0}$ & $6.27 \pm 0.53 \% *$ & $28.46 \pm 0.36 \% *$ & $11.87 \pm 0.33 \% *$ \\
$\mathbf{2 0}$ & $12.29 \pm 0.62 \% *$ & $31.16 \pm 0.35 \% *$ & $14.27 \pm 0.42 \% *$ \\
$\mathbf{4 0}$ & $16.88 \pm 0.29 \% *$ & $36.32 \pm 0.37 \% *$ & $19.01 \pm 0.14 \% *$ \\
$\mathbf{8 0}$ & $19.58 \pm 0.41 \% *$ & $40.93 \pm 0.33 \% *$ & $21.21 \pm 0.17 \% *$ \\
$\mathbf{1 6 0}$ & $24.71 \pm 0.26 \% *$ & $45.84 \pm 0.42 \% *$ & $28.31 \pm 0.39 \% *$ \\
\hline
\end{tabular}

The values represented are mean \pm SE, where $n=5$.

Mean values superscripted by $*$ are statistically significant at $p<0.05$.

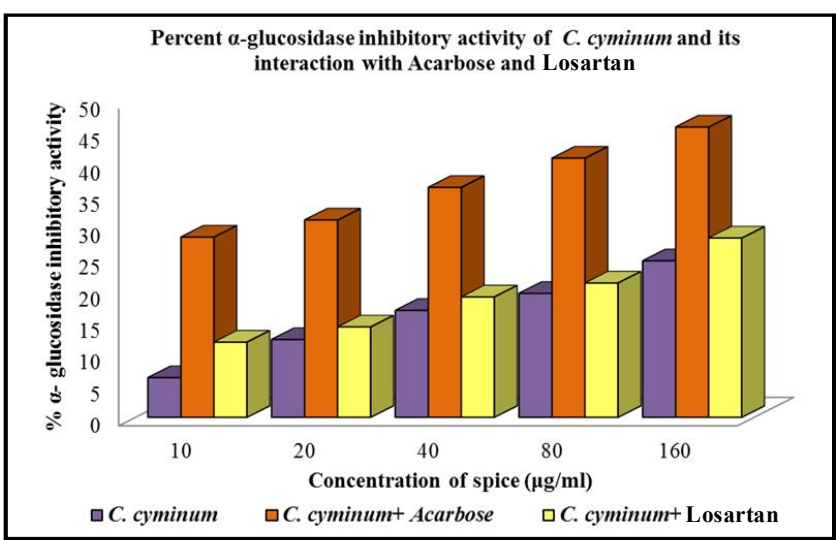

Figure 4b: Percent $\alpha$-glucosidase inhibitory activity of $C$. cyminum and its interaction with Acarbose and Losartan.

Table 8a: Percent $\alpha$-amylase inhibitory activity of L. nobilis and its interaction with Acarbose and Losartan

\begin{tabular}{|c|c|c|c|}
\hline $\begin{array}{c}\text { Concentration } \\
(\mathbf{g} / \mathbf{m l})\end{array}$ & L. nobilis & $\begin{array}{c}\text { L. nobilis }+ \\
\text { Acarbose } \\
\text { supplementation }\end{array}$ & $\begin{array}{c}\text { L. nobilis }+ \\
\text { Losartan } \\
\text { supplementation }\end{array}$ \\
\hline $\mathbf{1 0}$ & $4.19 \pm 0.35 \% *$ & $15.64 \pm 0.23 \% *$ & $15.79 \pm 0.24 \% *$ \\
$\mathbf{2 0}$ & $11.72 \pm 0.69 \% *$ & $22.58 \pm 0.28 \% *$ & $18.91 \pm 0.85 \% *$ \\
$\mathbf{4 0}$ & $15.59 \pm 0.58 \% *$ & $30.97 \pm 0.26 \% *$ & $26.85 \pm 0.28 \% *$ \\
$\mathbf{8 0}$ & $23.04 \pm 0.11 \% *$ & $38.99 \pm 0.19 \% *$ & $31.64 \pm 0.13 \% *$ \\
$\mathbf{1 6 0}$ & $24.57 \pm 0.19 \% *$ & $46.62 \pm 0.12 \% *$ & $38.12 \pm 0.16 \% *$ \\
\hline
\end{tabular}

The values represented are mean \pm SE, where $n=5$.

Mean values superscripted by $*$ are statistically significant at $p<0.05$.

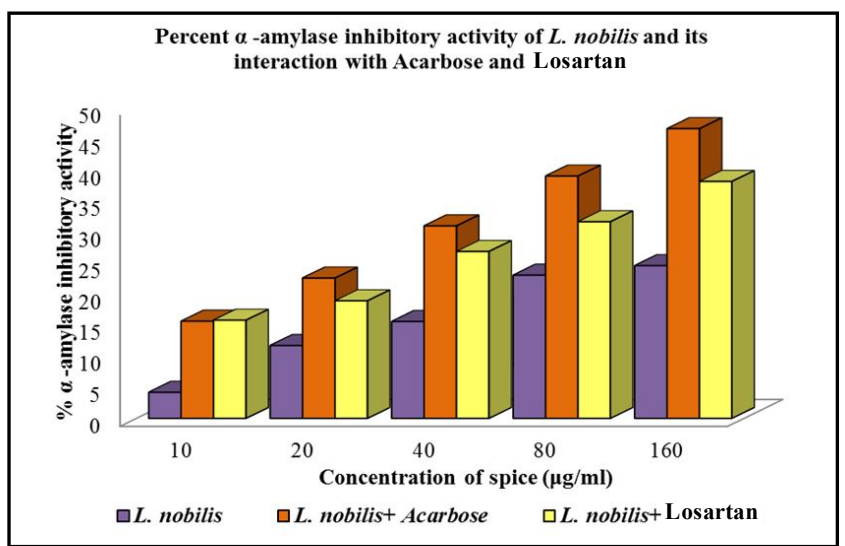

Figure 5a: Percent $\alpha$-amylase inhibitory activity of L. nobilis and its interaction with Acarbose and Losartan

Table 8b: Percent $\alpha$-glucosidase inhibitory activity of $L$. nobilis and its interaction with Acarbose and Losartan

\begin{tabular}{|c|c|c|c|}
\hline $\begin{array}{c}\text { Concentration } \\
(\mathbf{g} / \mathbf{m l})\end{array}$ & L. nobilis & $\begin{array}{c}\text { L. nobilis }+ \\
\text { Acarbose } \\
\text { supplementation }\end{array}$ & $\begin{array}{c}\text { L. nobilis }+ \\
\text { Losartan } \\
\text { supplementation }\end{array}$ \\
\hline $\mathbf{1 0}$ & $17.52 \pm 1.33 \% *$ & $32.12 \pm 0.22 \% *$ & $22.11 \pm 0.27 \% *$ \\
$\mathbf{2 0}$ & $21.48 \pm 1.50 \% *$ & $38.03 \pm 0.18 \% *$ & $28.70 \pm 0.28 \% *$ \\
$\mathbf{4 0}$ & $29.30 \pm 1.10 \% *$ & $40.98 \pm 0.32 \% *$ & $36.06 \pm 0.26 \% *$ \\
$\mathbf{8 0}$ & $33.60 \pm 1.07 \% *$ & $45.96 \pm 0.32 \% *$ & $40.85 \pm 0.23 \% *$ \\
$\mathbf{1 6 0}$ & $41.80 \pm 0.32 \% *$ & $48.94 \pm 0.25 \% *$ & $47.32 \pm 0.21 \% *$ \\
\hline
\end{tabular}

The values represented are mean \pm SE, where $n=5$.

Mean values superscripted by $*$ are statistically significant at $p<0.05$.

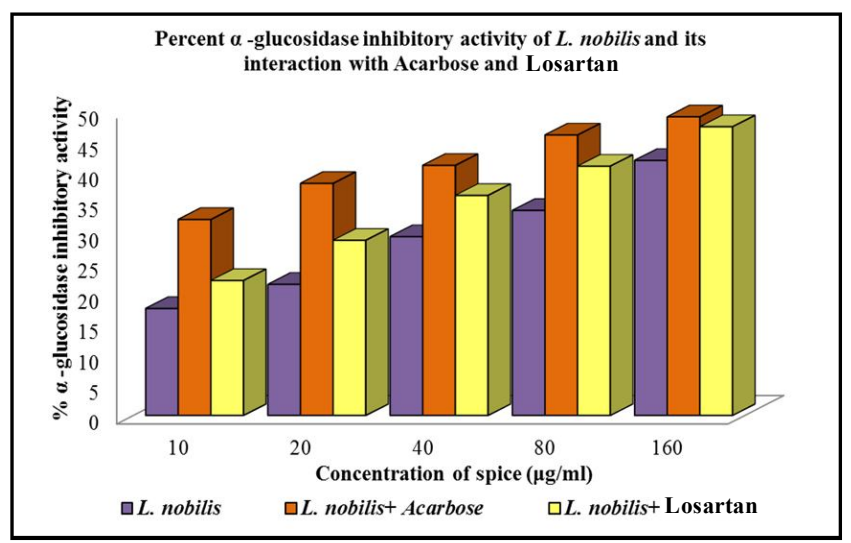

Figure 5b: Percent $\alpha$-glucosidase inhibitory activity of L. nobilis and its interaction with Acarbose and Losartan.

Table 9a: Percent $\alpha$-amylase inhibitory activity of P. nigrum and its interaction with Acarbose and Losartan

\begin{tabular}{|c|c|c|c|}
\hline $\begin{array}{c}\text { Concentration } \\
(\mathbf{g} / \mathbf{m l})\end{array}$ & $\boldsymbol{P}$ nigrum & $\begin{array}{c}\boldsymbol{P} \text { nigrum }+ \\
\text { Acarbose } \\
\text { supplementation }\end{array}$ & $\begin{array}{c}\boldsymbol{P} \text { nigrum }+ \\
\text { Losartan } \\
\text { supplementation }\end{array}$ \\
\hline $\mathbf{1 0}$ & $1.58 \pm 0.13 \% *$ & $27.86 \pm 0.25 \% *$ & $9.76 \pm 0.28 \% *$ \\
$\mathbf{2 0}$ & $4.01 \pm 0.30 \% *$ & $30.95 \pm 0.28 \% *$ & $13.38 \pm 0.46 \% *$ \\
$\mathbf{4 0}$ & $8.05 \pm 0.11 \% *$ & $35.87 \pm 0.26 \% *$ & $17.92 \pm 0.18 \% *$ \\
$\mathbf{8 0}$ & $11.56 \pm 0.58 \% *$ & $38.97 \pm 0.19 \% *$ & $21.98 \pm 0.25 \% *$ \\
$\mathbf{1 6 0}$ & $14.72 \pm 0.72 \% *$ & $41.22 \pm 0.24 \% *$ & $28.58 \pm 0.44 \% *$ \\
\hline
\end{tabular}

The values represented are mean $\pm S E$, where $n=5$.

Mean values superscripted by $*$ are statistically significant at $p<0.05$. 


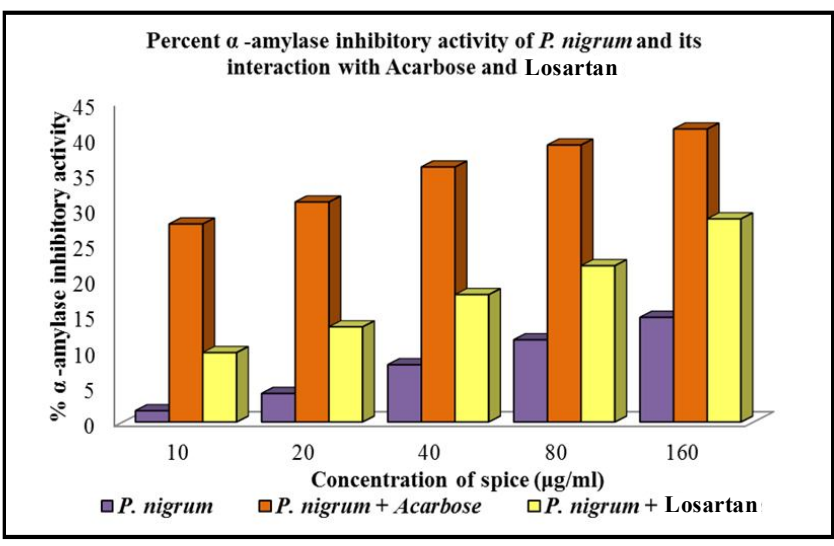

Figure 6a: Percent $\alpha$-amylase inhibitory activity of $P$. nigrum and its interaction with Acarbose and Losartan.

Table 9b: Percent $\alpha$-glucosidase inhibitory activity of $P$. nigrum and its interaction with Acarbose and Losartan

\begin{tabular}{|c|c|c|c|}
\hline $\begin{array}{c}\text { Concentration } \\
(\mathbf{g} / \mathbf{m l})\end{array}$ & $\boldsymbol{P}$ nigrum & $\begin{array}{c}\boldsymbol{P} \text { nigrum }+ \\
\text { Acarbose } \\
\text { supplementation }\end{array}$ & $\begin{array}{c}\boldsymbol{P} \text { nigrum }+ \\
\text { Losartan } \\
\text { supplementation }\end{array}$ \\
\hline $\mathbf{1 0}$ & $13.26 \pm 0.48 \% *$ & $22.47 \pm 0.27 \% *$ & $11.8 \pm 0.32 \% *$ \\
$\mathbf{2 0}$ & $16.80 \pm 0.25 \% *$ & $25.63 \pm 0.25 \% *$ & $18.94 \pm 0.28 \% *$ \\
$\mathbf{4 0}$ & $20.40 \pm 0.34 \% *$ & $28.86 \pm 0.32 \% *$ & $23.78 \pm 0.34 \% *$ \\
$\mathbf{8 0}$ & $23.73 \pm 0.51 \% *$ & $31.26 \pm 0.31 \% *$ & $28.80 \pm 0.25 \% *$ \\
$\mathbf{1 6 0}$ & $35.02 \pm 0.10 \% *$ & $38.68 \pm 0.41 \% *$ & $35.74 \pm 0.21 \% *$ \\
\hline
\end{tabular}

The values represented are mean \pm SE, where $n=5$.

Mean values superscripted by $*$ are statistically significant at $p<0.05$.

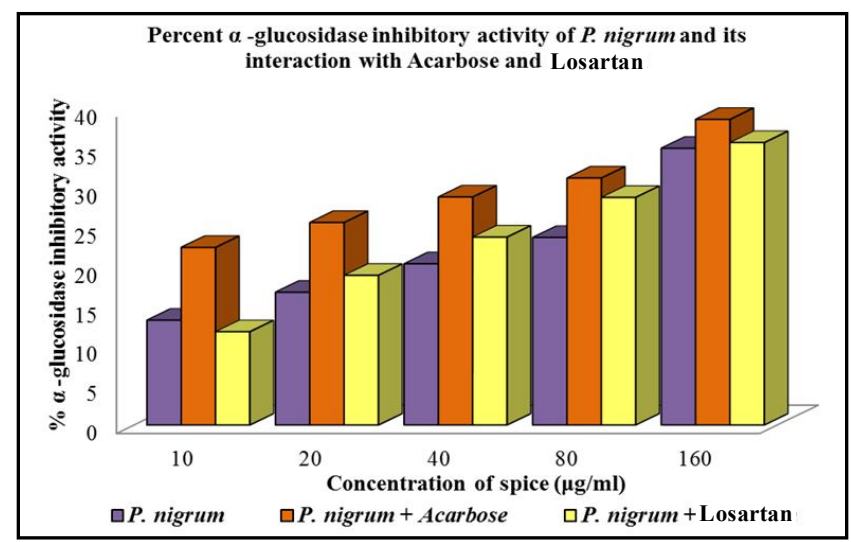

Figure 6b: Percent $\alpha$-glucosidase inhibitory activity of $P$. nigrum and its interaction with Acarbose and Losartan.

Table 10a: Percent $\alpha$-amylase inhibitory activity of E. cardamomum and its interaction with Acarbose and Losartan

\begin{tabular}{|c|r|c|c|}
\hline $\begin{array}{c}\text { Concentration } \\
(\mathbf{g} / \mathbf{m l})\end{array}$ & E. cardamomum & $\begin{array}{c}\text { E. cardamomum }+ \\
\text { Acarbose } \\
\text { supplementation }\end{array}$ & $\begin{array}{c}\text { E. cardamomum } \\
\text { Losartan } \\
\text { supplementation }\end{array}$ \\
\hline $\mathbf{1 0}$ & $5.26 \pm 0.34 \% *$ & $15.04 \pm 0.16 \% *$ & $13.86 \pm 0.24 \% *$ \\
$\mathbf{2 0}$ & $9.68 \pm 0.28 \% *$ & $22.92 \pm 0.20 \% *$ & $16.86 \pm 0.17 \% *$ \\
$\mathbf{4 0}$ & $12.14 \pm 0.36 \% *$ & $31.01 \pm 0.30 \% *$ & $22.13 \pm 0.30 \% *$ \\
$\mathbf{8 0}$ & $16.55 \pm 0.35 \% *$ & $36.97 \pm 0.25 \% *$ & $28.96 \pm 0.27 \% *$ \\
$\mathbf{1 6 0}$ & $24.43 \pm 0.08 \% *$ & $42.66 \pm 0.17 \% *$ & $37.19 \pm 0.13 \% *$ \\
\hline
\end{tabular}

The values represented are mean $\pm S E$, where $n=5$.

Mean values superscripted by $*$ are statistically significant at $p<0.05$.

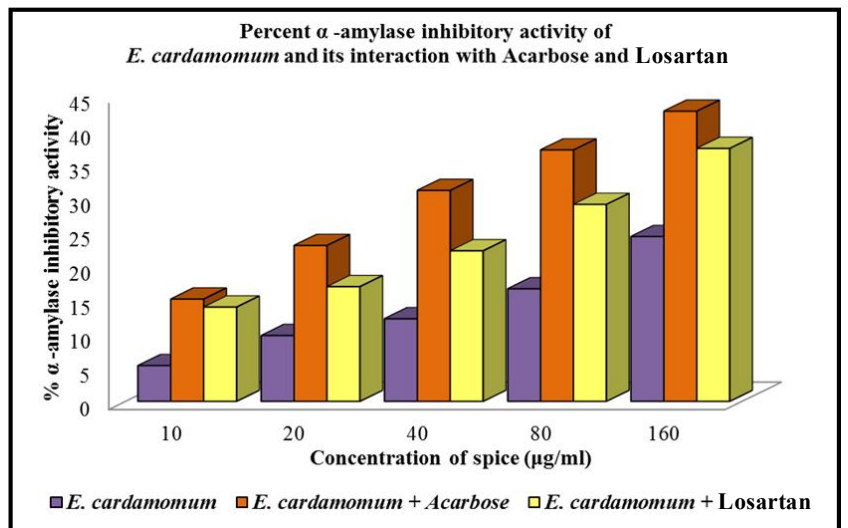

Figure 7a: Percent $\alpha$-amylase inhibitory activity of E. cardamomum and its interaction with Acarbose and Losartan.

Table 10b: Percent $\alpha$-glucosidase inhibitory activity of E. cardamomum and its interaction with Acarbose and Losartan

\begin{tabular}{|c|c|c|c|}
\hline $\begin{array}{c}\text { Concentration } \\
(\mathrm{g} / \mathrm{ml})\end{array}$ & E. cardamomum & $\begin{array}{c}\text { E. cardamomum }+ \\
\text { Acarbose } \\
\text { supplementation }\end{array}$ & $\begin{array}{l}\text { E. cardamomum }+ \\
\text { Losartan } \\
\text { supplementation }\end{array}$ \\
\hline $\mathrm{g} / \mathrm{ml}$ & $17.83 \pm 0.50 \% *$ & $27.69 \pm 0.25 \% *$ & $26.82 \pm 0.22 \% *$ \\
\hline $\mathrm{g} / \mathrm{ml}$ & $25.10 \pm 0.80 \% *$ & $30.78 \pm 0.26 \% *$ & $32.02 \pm 0.24 \% *$ \\
\hline $\mathrm{g} / \mathrm{ml}$ & $31.49 \pm 0.78 \% *$ & $36.70 \pm 0.26 \% *$ & $37.03 \pm 0.26 \% *$ \\
\hline $\mathrm{g} / \mathrm{ml}$ & $37.85 \pm 0.42 \% *$ & $42.18 \pm 0.27 \% *$ & $42.80 \pm 0.27 \% *$ \\
\hline $160 \mathrm{~g} / \mathrm{ml}$ & $43.91 \pm 0.42 \% *$ & $47.75 \pm 0.20 \% *$ & $49.07 \pm 0.29 \% *$ \\
\hline
\end{tabular}

The values represented are mean \pm SE, where $n=5$.

Mean values superscripted by $*$ are statistically significant at $p<0.05$.

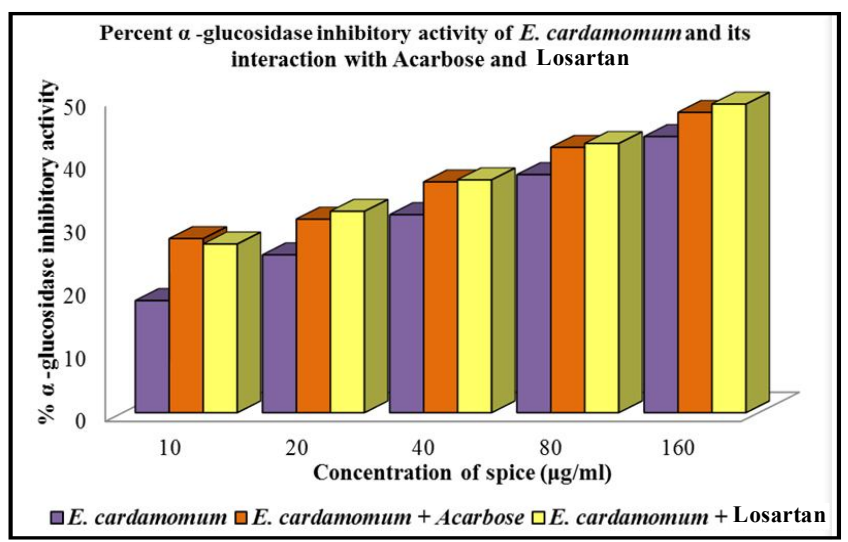

Figure $7 \mathbf{b}$ : Percent $\alpha$-glucosidase inhibitory activity of E. cardamomum and its interaction with Acarbose and Losartan.

The depression of $\mathrm{IC}_{50}$, on drug supplementation, is presented in Table 5.

Further, the data was analyzed to find the percent enhancement of enzyme inhibitory activities and is represented in Table 11 . The same was calculated as:

$\frac{\mathrm{IC}_{50} \text { of spice }-\mathrm{IC}_{50} \text { on drug supplementation }}{\mathrm{IC}_{50} \text { of spice }} \times 100$ 
Table 11: Percent enhancement of effectiveness of $\alpha$-amylase and $\alpha$-glucosidase inhibitory activities on Acarbose and Losartan supplementation

\begin{tabular}{|c|c|c|c|c|}
\hline \multirow[t]{2}{*}{ Spices } & \multicolumn{2}{|c|}{$\begin{array}{l}\text { \% Enhancement of effectiveness of } \\
\alpha \text {-amylase inhibitory activity }\end{array}$} & \multicolumn{2}{|c|}{$\begin{array}{l}\text { \% Enhancement of effectiveness of } \\
\alpha \text {-glucosidase inhibitory activity }\end{array}$} \\
\hline & $\begin{array}{c}\text { Acarbose } \\
\text { supplementation }\end{array}$ & $\begin{array}{c}\text { Losartan } \\
\text { supplementation }\end{array}$ & $\begin{array}{c}\text { Acarbose } \\
\text { supplementation }\end{array}$ & $\begin{array}{c}\text { Losartan } \\
\text { supplementation }\end{array}$ \\
\hline $\begin{array}{l}\text { C. zeylanicum } \\
\text { C. cyminum } \\
\text { L. nobilis } \\
P . \text { nigrum } \\
\text { E. cardamomum }\end{array}$ & $\begin{array}{l}74.52 \% \\
62.64 \% \\
53.58 \% \\
56.77 \% \\
50.36 \%\end{array}$ & $\begin{array}{l}28.19 \% \\
48.34 \% \\
34.10 \% \\
41.73 \% \\
37.46 \%\end{array}$ & $\begin{array}{l}38.49 \% \\
52.42 \% \\
25.14 \% \\
-0.11 \% \\
10.46 \%\end{array}$ & $\begin{array}{c}19.85 \% \\
5.40 \% \\
20.05 \% \\
7.91 \% \\
16.06 \%\end{array}$ \\
\hline
\end{tabular}

\section{Discussion}

Selected antidiabetic properties, namely $\alpha$-amylase and $\alpha$-glucosidase inhibitory activities for C. zeylanicum, C. cyminum, L. nobilis, $P$. nigrum, and E. cardamomum were evaluated using widely established, sensitive, specific, validated and internationally accepted bioassays in vitro. As per conclusions drawn by Adisakwattana et al. (2011), $\alpha$-amylase and $\alpha$-glucosidase are the key enzymes involved in starch digestion. Thus, in the management of diabetes, inhibitors of these enzymes can play a key therapeutic role.

Active phytochemicals, such as alkaloids, tannins, phenols, saponins, terpenoids, flavonoids, steroids, and sterols, themselves or in conjunction, mediate the medicinal properties of a spice/plant. Varied methods and solvents can be employed for the extraction of these phytochemicals, which govern the pharmacokinetics and pharmacodynamics of the spice. Most of the phytochemicals are extracted well in organic solvents as compared to water. Widely used organic solvents for extraction include methanol, ethanol, dichloromethane, chloroform and acetone (Premakumara et al., 2017; Salve and Mule, 2018; Upadhyay, 2016). However, all of them are associated with toxic effects on human physiology. Thus, for the current study, $50 \%$ hydroacetone was the 'solvent of choice' as the toxicity associated with this solvent system is minimal. The scientific literature regarding the applicability of hydroacetone is largely limited and this highlights the uniqueness of our study.

Amongst the reported phytochemicals, the antidiabetic effects of a few are mentioned by Emeka and Asuzu (2018). Flavonoids constitute a family of soluble polyphenols and their antidiabetic properties are attributed partly to its antioxidant potentials and partly to its ability to modulate cell signaling. Flavonoids such as naringenin and cyanidin are reported to inhibit amylase and glucosidase (Li et al., 2006; Priscilla et al., 2014; Akkarachiyasit et al., 2010). Saponins are major plant metabolites that naturally occur as surface-active glycosides and induce insulin production, amelioration of oxidative stress and advanced glycation end products (AGEs) formation (Jiang et al., 1999). Also, saponins promote insulin release from the pancreas (Ali and Adanlawo, 2012) and inhibit $\alpha$-amylase and $\alpha$-glucosidase (Hemlatha et al., 2010). Alkaloids contain basic nitrogen atoms and cause significant elevation of plasma insulin, decrease in serum lipids and lipid peroxide formation (Khalil et al., 2007). It has been reported by Sharma et al. (2009), that there also is a significant improvement of GLUT 4, glucokinase activity, attenuation of glucose-6phosphatase activity and improvement in the hepatic glycogen content. Tannins are polyphenolic biomolecules, exhibiting antidiabetic effects mainly by inhibiting the $\alpha$-amylase and $\alpha$ glucosidase activities (Kunyanga et al., 2011) and stimulating

transportation of glucose (Liu et al., 2005). Terpenoids have demonstrated hypoglycemic potentials (Zhang et al., 2009) affecting translocation of GLUT 4 (Huang et al., 2010) and also inhibition of $\alpha$-glucosidase activities (Matsuda et al., 1999).

As per the phytochemical and biomolecule analysis of the spices under consideration, using hydroacetone as the solvent, all the spices demonstrated the presence of flavonoids as well as tannins, both of which possess the ability to inhibit the carbohydrate metabolizing enzymes amylases and glucosidases, in vitro. The $\alpha$-amylase inhibitory activities as demonstrated by the spices studied were better for E. cardamomum and L. nobilis, while for $\alpha$-glucosidase inhibitory activity, the spice depicting better activity was E. cardamomum.

Complementary and Alternative Medicine (CAM) is being used by around $80 \%$ of the present-day global population as an alternative to conventional medicine (Malagi et al., 2014). Chang et al. (2007) reported the use of herbal medicine, dietary supplements, and CAM therapies by about $72.8 \%$ diabetics, along with the mainstream treatments (Liu et al., 2015). The same can be beneficial, as well as, can possess potential risks in effective management of the disorder. For diabetics, a combination therapy is suggested to ameliorate the other complications associated with it. (Curtis, 2006; Murthy et al., 2013; Gupta et al., 2017b).

This prompted us to consider this exclusive study on the antidiabetic effect of spices in conjugation with two of the most commonly used drugs, viz., Acarbose and Losartan. The commercially available drugs were used for the same. The drugs were screened for their $\alpha$-amylase and $\alpha$-glucosidase inhibitory activities at various concentrations and it was observed that beyond $5000 \mu \mathrm{g} / \mathrm{ml}$ Acarbose, the $\alpha$-amylase inhibitory activity reached saturation of $22 \%$ while $\alpha$-glucosidase inhibitory activity was saturated at $45 \%$. In the case of Losartan at $1600 \mathrm{~g} / \mathrm{ml}$, the $\alpha$-amylase and $\alpha$-glucosidase inhibitory activities saturated at $22 \%$ and $41 \%$, respectively. Thus, these concentrations were used for supplementation with the spices, as the aim of the study was to evaluate the modulation of inhibitory activity of the spices under the normal drug regime.

The results on statistical analysis depict a significant increase in inhibitory activities of both the enzymes in the presence of the drugs. The results suggest that for the spices, viz., C. zeylanicum, C. cyminum, L. nobilis, P. nigrum and E. cardamomum, the percent enhancement in presence for Acarbose was 74.52, 62.65, 53.58, 56.76 and $50.35 \%$, respectively for the $\alpha$-amylase inhibitory activity while it was $28.19,48.34,34.1,41.73$ and $37.46 \%$, respectively in presence of Losartan. Further, for the $\alpha$-glucosidase inhibitory activity 
of the spices as mentioned above, the enhancement of inhibitory activity was $38.48,52.42,25.14,-0.11,10.46 \%$, respectively on Acarbose supplementation and $19.85,5.40,20.05,8.12,16.06 \%$ on Losartan supplementation. Thus, modulation of inhibitory activity generally is higher for Acarbose than Losartan for both enzymes considered, except in case of $P$. nigrum where negligible difference was observed in presence of Acarbose for $\alpha$-glucosidase inhibitory activity.

Such interactions have largely been neglected and such spice-drug interactions can lead to hypoglycemic conditions which could be fatal.

\section{Conclusion}

The current results indicate that all the five-spice extracts showed good inhibitory activity towards $\alpha$-amylase and $\alpha$-glucosidase, and hence, the spices can be used as dietary supplements to control postprandial increase in blood glucose levels. The spices essentially contain herbal bioactive compounds having enzyme inhibitory potential and thus, further structural elucidation and characterization of the bioactive constituents is required. The present study is a stepping stone towards the development of nutraceuticals with minimum adverse reactions. Further studies with focus on investigating effects in vivo are being considered.

Currently, the medical academic curriculum lacks data on spice-drug or a larger perspective of plant-drug interactions. To enable better therapy, a merger of ancient scientific knowledge along with the use of medicines is the need of the hour. This study opens up the possibility for the search of such interactions, which may be the two sides of a coin, leading to benefits and/or health impairment.

\section{Acknowledgements}

Financial support to the department from Shri Vile Parle Kelavani Mandal (SVKM), is gratefully acknowledged. The authors are grateful to Dr. Bindu Gopalakrishnan (Department of Botany) for authenticating the spice samples, and Mr. Pravin More (Department of Physics), Mithibai College (Autonomous) for helping with physical parameter estimation.

\section{Conflict of interest}

The authors declare that there are no conflicts of interest in the course of conducting the research. All the authors had final decision regarding the manuscript and decision to submit the findings for publication.

\section{References}

Abdulrahim Aljamal (2011). Effects of bay leaves on the patients with Diabetes Mellitus. Res. J. Med. Plants, 5:471-476.

Adisakwattana, S.; Lerdsuwankij, O.; Poputtachai, U.; Minipun, A. and Suparpprom, C. (2011). Inhibitory activity of cinnamon bark species and their combination effect with acarbose against intestinal $\alpha$ glucosidase and pancreatic $\alpha$-amylase. Plant Foods Hum. Nutr., 66(2): $143-148$.

Aghasi, M.; Ghazi-Zahedi, S.; Koohdani, F.; Siassi, F.; Nasli-Esfahani, E.; Keshavarz, A.; Qorbani, M; Hoorieh Khoshamal, Asma Salari-Moghaddam and Sotoudeh, G. (2018). The effects of green cardamom supplementation on blood glucose, lipids profile, oxidative stress, sirtuin-1 and irisin in type 2 diabetic patients: A study protocol for a randomized placebocontrolled clinical trial. BMC Complement Altern. Med., 18(1):20682066 .
Aghasi, M.; Koohdani, F.; Qorbani, M.; Nasli-Esfahani, E.; Ghazi-Zahedi, S.; Khoshamal, H.; Keshavarz, A. and Sotoudeh, G. (2019). Beneficial effects of green cardamom on serum SIRT1, glycemic indices and triglyceride levels in patients with type 2 diabetes mellitus: A randomized doubleblind placebo controlled clinical trial. J. Sci. Food Agric., 99(8):39333940 .

Ahmed, A.S.; Ahmed, Q.; Saxena, A.K. and Jamal, P. (2017). Evaluation of in vitro antidiabetic and antioxidant characterizations of $E$. cardamomum (L.) Maton (Zingiberaceae), Piper cubeba L. f. (Piperaceae), and Plumeria rubra L. (Apocynaceae). Pak. J. Pharm. Sci., 30(1):113-126.

Akkarachiyasit, S.; Charoenlertkul, P.; Yibchok-Anun, S. and Adisakwattana, S. (2010). Inhibitory activities of cyanidin and its glycosides and synergistic effect with acarbose against intestinal $\alpha$-glucosidase and pancreatic $\alpha$-amylase, Int. J. Mol. Sci., 11(9):3387-3396.

Ali Al-Samydai, Farah, Al-Mamoori, Mayada, S. and Hudaib, M. (2018). Antidiabetic activity of Cinnamon: A Review. International Research Journal of Pharmacy and Medical Sciences (IRJPMS), 1(5):43-45.

Alli, S.Y. R. and Adanlawo, I. G. (2012). Hypoglycaemic effect of saponin from the root of Garcinia kola on alloxan-induced diabetic rats. J. Drug Deliv. Ther., 2:9-12.

American Diabetes Association (2010). Diagnosis and classification of diabetes mellitus. Diabetes Care, 33(1):S-62-69.

Balaji, R.M.; Chitra Jeyaram, K.; Sundaram, M. and Ramasamy, M.S. (2015). Studies on antidiabetic activity of indian Medicinal Plants usingAmylase and-Glucosidase inhibitory activity:A Pathway to Antidiabetic Drugs. World Journal of Medical Sciences, 12(3):207212.

Bandigari, P.; Mohammed, A.; Arikilla, S.; Chanduri, B.; Yemba, S. and Chinnala, K.M. (2018). Evaluation of antidiabetic activity of seeds of black pepper in streptozotocin induced diabetic rats. Eur. J. Biomedical Pharmaceutical Sci., 5(5):1082-1087.

Berawi K.N.; Shidarti, L.; Nurdin, S.U.; Lipoeto, N.I.; Wahid, I.; Jamsari, J. and Nurcahyani, E. (2017). Comparison effectiveness of antidiabetic activity extract herbal mixture of soursop leaves (Annona Muricata), bay leaves (Syzygium Polyanthum) and pegagan leaves (Centella Asiatica). Bio. Med. Pharmacol. J., 10(3).

Chang, H.Y.; Wallis, M. and Tiralongo, E. (2007). Use of complementary and alternative medicine among people living with diabetes: Literature review. J. Adv. Nurs., 58(4):307-319.

Chaudhury, A.; Duvoor, C.; Reddy V.S. D.; Kraleti S.; Chada, A.; Ravilla, R.; Marco, A.; Shekhawat, N.S.; Theresa, M. M.; Kuriakose, K.; Sasapu, A.; Beebe, A.; Patil, N.; Musham, C. K.; Lohani , G. P. and Mirza, W. (2017). Clinical review of Antidiabetic Drugs: Implications for type 2 Diabetes Mellitus Management. Front Endocrinol. (Lausanne), 8:(6):1-12.

Curtis, T. (2006). Drug interactions of medications commonly used in diabetes. Diabetes Spectrum, 19(4):202-211.

Dahanayake, J.M.; Perera, P.K.; Galappatty, P.; Perera, H.D.S.M.; and Arawwawala L.D.A.M. (2019). Comparative phytochemical analysis and antioxidant activities of tamalakyadi decoction with its modified dosage forms. Evidence-Based Complementary and Alternative Medicine; Article ID 6037137:9. doi.org/10.1155/2019/6037137

Emeka, P.A. and Asuzu, I.A. (2018). Mechanisms of actions of some bioactive antidiabetic principles from phytochemicals of medicinal plants: A review. Indian Journal of Natural Products and Resources, 9(2):85-96.

Fang, F.; Sang, S.; Chen, K.Y.; Gosslau, A.; Ho, C.T. and Rosen, R.T. (2005). Isolation and identification of cytotoxic compounds from Bay leaf ( $L$. nobilis). Food Chem., 93:497-501. 
Geng, P.; Yang, Y.; Gao, Z; Yu, Y.; Shi, Q. and Bai, G. (2007). Combined effect of total alkaloids from Feculae Bombycis and natural flavonoids on diabetes. J. Pharm. Pharmacol., 59:1145-1150.

Gupta, R.C.; Chang, D.; Nammi, S.; Bensoussan, A. and Bilinski, K. (2017a). Interactions between antidiabetic drugs and herbs: An overview of mechanisms of action and clinical implications. Diabetol. Metab. Syndr. 9:59. DOI 10.1186/s13098-017-0254-9

Gupta, R.C.; Chang, D.; Nammi, S.; Bensoussan, A.; Bilinski, K. and Roufogalis, B.D. (2017b). Interactions between antidiabetic dr gs and herbs: An overview of mechanisms of action and clinical implications. Diabetol. Metab. Syndr., 9:59

Hemlatha, T.; Pulavendran, S.; Balachandran, C.; Manohar, B.M. and Puvanakrishnan, R. (2010). Arjunolic acid: A novel phytomedicine with multifunctional therapeutic applications. Indian J. Exp. Biol., 48:238247 .

Huang, X.; Fu, J.F. and Di, D.L. (2010). Preparative isolation and purification of steviol glycosides from Stevia rebaudiana Bertoni using highspeed counter-current chromatography, Sep. Purif. Technol., 71(2):220-224

Jafari, S.; Sattari, R. and Ghavamzadeh, S. (2017). Evaluation the effect of 50 and $100 \mathrm{mg}$ doses of $C$. cyminum essential oil on glycemic indices, insulin resistance and serum inflammatory factors on patients with diabetes type II: A double-blind randomized placebo-controlled clinical trial. J. Tradit. Complement Med., 7(3):332-338.

Jiang, Q. L.; Li, Y. J.; Xin, H.; Jiang, J.W.; Lu, X.X., et al., (1999). Effects of ASI on insulin and C-peptide, Heilongjiang Med. Pharm., 22:14.

Joshi, S.G. (2000). Medicinal plants: Family Apiaceae, 1st edn. Oxford and IBH Publishing Co. Pvt. Ltd, New Delhi, pp:34-35.

Kamath, K.J.and Adiga, S.H. (2014). Herb-Dr g Interaction in Diabetes: A Bane or a Boon. J. Diabetes Metab. Disord. Control, 1(3).

Kamble, S. and Rambhimaiah, S. (2013). Antidiabetic activity of aqueous extract of Cinnamomum cassia in Alloxan-Induced Diabetic Rats. Bio. Med. Pharmacol. J., 6(1).

Kavitha, S.; Rameshkannan, M. V.; Mani. P. (2018). Analysis of antioxidant and antidiabetic activity of $P$. nigrum Leaf extract by in vitro assay. IOSR Journal of Pharmacy and Biological Sciences (IOSR-JPBS), 13(2)II:53-56

Khalil, Abou El-Soud M.Y.; Hussein, F.S.H. and Hussein, F.A. R. (2007). Antidiabetic effects of Fen greek alkaloid extract in streptozotocin induced hyperglycemic rats. J. App. Sci. Res., 3(10):1073-1083.

Khaliq, T.; Sarfraz, M. and Ashraf, M.A. (2015). Recent progress for the utilization of Curcuma longa, P. nigrum and Phoenix dactylifera seeds against type 2 diabetes. West Indian Med. J. Dec., 64(5):527532

Khan, A.; Safdar, M.; Ali Khan, M.M.; Khattak, K.N. and Anderson, R.A. (2003) Cinnamon improves glucose and lipids of people with type 2 diabetes. Diabetes Care, 26:3215-3218.

Khan, A.; Zaman, G. and Anderson, R.A. (2009). Bay leaves improve glucose and lipid profile of people with type 2 diabetes. J. Clin. Biochem. Nutr., 44(1):52-56.

Kunyanga, C.N.; Imungi, J.K.; Okoth, M.; Momanyi, C.; Biesalski, H.K. et al. (2011). Antioxidant and antidiabetic properties of condensed tannins in acetonic extract of selected raw and processed indigenous food ingredients from Kenya. J. Food Sci.; 76(4):560-567.

Lebovitz, H.E. (1998). Alpha glucosidase inhibitors as agents in the treatment of Diabetes" Diabetes Rev., 6(22):132-145.
Li, J. M.; Che, C.T.; Lau, C. B. S.; Leung, P. S. and Cheng, C. H. K. (2006). Inhibition of intestinal andrenal $\mathrm{Na}+$-glucose co-transporter by naringenin, Int. J. Biochem. Cell Biol., 38:985-995.

Liu, M.Z; Yue-Li Z; Mei-Zi; Zeng Fa-Zhong H.; Zhi-Ying Luo; Jian-Quan Luo; JiaGenWen; Xiao-Ping Chen; Hong-Hao Zhou, and Zhang, W. (2015). Pharmacogenomics and herb-drug interactions: Merge of future and tradition. Evidence-based complementary and alternative medicine, Article ID 321091:8. http://dx.doi.org/10.1155/2015/ 321091

Liu, X.; Kim, J.; Li, Y.; Liu, F. and Chen, X. (2005). Tannic acid stimulates glucose transport and inhibits adipocyte differentiation in 3T3-L1 cells. J. Nutr. 135(2):165-171.

Malagi, K.J.; Kamath, M. and Adiga, S.H. (2014). Herb-drug interaction in diabetes: A bane or a boon. Journal of Diabetes, Metabolic Disorders and Control, 1(3):13-18.

Matsuda, H.; Murakami, T.; Yashiro, K.; Yamahara, J. and Yoshikawa, M. (1999) Antidiabetic principles of natural medicines. IV.1. Aldose reductase and a-glucosidase inhibitors from the roots of Salacia oblonga WALL. (Celastraceae): Structure of a new friedelane-type triterpene, kotalagenin 16-acetate, Chem. Pharm. Bull., 47(12):1725-1729.

Modi, M.C.; Ladumor C.V.; Patel, D.; Patel B. H..; Solanki, L. S. and Bhadarka, H. D. (2018). Phytochemical analysis and comparative study of in vitro free radical scavenging activity of different extracts of leaves of Abrus precatorius L. Ann. Phytomed., 7(2):133-137.

Mohanty, B. (2018). Choosing the best oral diabetic agents in $T 2$ diabetes mellitus physicians challenge. J. Diabetes Metab., 9:6.

Murthy, T.E.G.K.; Kommineni, M.K. and Mayuren, C. (2013). Influence of losartan on the hypoglycemic activity of glimepiride in normal and diabetic rats. Ther. Adv. Endocrinol. Metab., 4(5):133-138. doi: $10.1177 / 2042018813509397$

Narkhede, M.B.; Ajimire, P.V.; Wagh,A.E.; Mohan, M. and Shivashanm gam, A.T (2011). In vitro antidiabetic activity of Caesalpina digyna (R.) methanol root extract. Asian Journal of Plant Science and Research, 1(2): 101-106.

Oboh, G; Akinbola, I.; Ademosun, A.; Sanni. D.; Odubanjo, O.; Olasehinde, T. and Oyeleye, S. (2015). Essential oil from Clove Bud (E genia aromatica Kuntze) Inhibit key enzymes relevant to the management of type 2 Diabetes and some Pro oxidant induced lipid Peroxidation in Rat Pancreas in vitro. J. Oleo. Sci. 64(7):775-782.

Patil, P.H.; Nandedkar, R.Y.; Shah, V.S. and Surana, S. J. (2013). Traditional Indian spices useful in Diabetes Mellitus: An updated review. J. Pharm. Bio. Sci., 4:157-161.

Premakumara, S.; Arachchige, G; Prabhashini, W.; Mendis, K.; Abeysekera, and Wanigasekera D.R. (2017). Antiamylase, Anticholinesterases, Antiglycation, and glycation reversing potential of bark and leaf of Ceylon Cinnamon (C. zeylanicum Blume) In vitro Evidence-Based Complementary and Alternative Medicine, Article ID 5076029:13. https://doi.org/10.1155/2017/5076029

Prevalence of diabetes and prediabetes in 15 states of India: results from the ICMR-INDIAB population-based cross-sectional study. (2017). Lancet: Diab. Endrocrinol., 5(8):585-596.

Priscilla, D.H.; Roy, D.; Suresh, A.; Kumar, V. and Thirumur gan, K. (2014). Naringenin inhibits $\alpha$-glucosidase activity: A promising strategy for the regulation of postprandial hyperglycemia in high fat diet fed streptozotocin induced diabetic rats. Chemico-Biol. Interactions, 210:77-85

Salve, J. T. and Mule, J.R. (2018). Phytochemical analysis of some selected spices. International Journal of Researches In Biosciences, Agriculture and Technology, 6(S2):244-249. 
Sharma, B.; Salunke, R.; Balomajumder, C.; Daniel, S. and Roy, P. (2009). Antidiabetic potential of alkaloid-rich fraction from Capparis deciduas on diabetic mice, J. Ethnopharmacol., 127:457-462.

Sharma, S.; Sharma, J. and Kaur, G. (2011). Therapeutic uses of Elettaria cardomum. Int. J. Drug Develop. Res., 2:102-108.

Sindhu, S.; Nair, V. K. and Mishra, A. (2013). In vitro studies on alpha amylase and alpha glucosidase inhibitory activities of selected plant extracts. Eur. J. Exp. Biol., 3(1):128-132.

Singh, J.; Parasuraman, S. and Kathiresan, S. (2018). Antioxidant and antidiabetic activities of methanolic extract of Cinnamomum cassia. Pharmacog. Res., 10:237-242.

Soni, A. and Sosa, S. (2013). Phytochemical Analysis and Free Radical Scavenging Potential of Herbal and Medicinal Plant Extracts. J. Pharmacog. Phytochem., 2(4):22-29.

Srivsatava, R.; Srivastava, S.P.; Jaiswal, N.; Mishra,A.; Maurya, R. and Srivastava, A.K. (2013). Antidiabetic and antidyslipidemic activities of $C$. cyminum L. in validated animal models. Med. Chem. Research, 20(9).

Subbulakshmi, G.; Naik, M. (2001). Indigenous foods in the treatment of Diabetes Mellitus. Bom. Hosp. Res. J., 43:548-561.
Suneetha, W.J. and Krishnakantha, T.P. (2005). Cardamom extract as inhibitor of human platelet aggregation. Phytother Res., 19:437-440.

Upadhyay, R.V. (2016). Antidiabetic potential of plant natural products: A review. Int. J. Green Pharmacy, 10(3):96-114.

Whiting, D.R.; Guariguata, L.; Weil, C. and Shaw, J. (2011). IDF Diabetes Atlas: Global estimates of the prevalence of diabetes for 2011 and 2030. Diab. Res. Clin. Pract., 94:311-321.

Wild, S.; Roglic, G., Green, A., Sicree, R. and King, H. (2004). Global Prevalence for Diabetes-estimates for the year 2000 and projections for the year 2030. Diabetes Care, 27(3):1047-1053.

Winarsi, H.; Sasongko, N.D.; Purwanto, A. and Nuraeni, I. (2014). Effect of cardamom leaves extract as antidiabetic, weight lost and hypocholesterolemic to alloxan-induced Sprague Dawley diabetic rats. Int. Food Res. J., 21(6):2253-2261.

Zhang, Z; Jiang, J.; Yu, P.; Zeng, X. and Larrick, J.W. (2009). Hypoglycemic and beta cell protective effects of andrographolide analogue for diabetes treatment. J. Transl. Med., 7:62.

Citation: Nupur Mehrotra, Kaustubh Jadhav, Swati Rawalgaonkar, Sara Anees Khan and Badal Parekh (2019). In vitro evaluation of selected Indian spices for $\alpha$-amylase and $\alpha$-glucosidase inhibitory activities and their spice-drug interactions. Ann. Phytomed., 8(2):43-54. 